\title{
Ekranisasi dan Relevansinya dalam Pembelajaran Bahasa Indonesia di Sekolah
}

\section{Rudi Karma ${ }^{1}$ \\ Andi Saadillah ${ }^{2}$}

\section{Universitas Sembilanbelas November Kolaka}

1rudikarmausn@gmail.com

${ }^{2}$ saadillahandi@gmail.com

\begin{abstract}
Abstrak
Penelitian ini dilatarbelakangi adanya perkembangan era digital industri perfileman tanah air sekarang ini sangatlah mengalami perkembangan pesat menjadi industri kreatif yang cukup menjanjikan. Pada perkembangannya bermunculan karya sastra khususnya novel yang diadaptasi untuk diangkat menjadi karya film. Proses adaptasi novel menjadi film yang merupakan perubahan substansi dari wacana yang dikenal dengan istilah proses ekranisasi. Tujuan penelitian ini adalah (1) mendeskripsikan proses ekranisasi berupa penciutan, penambahan, ataupun perubahan variasi dari alur cerita Novel ke Film Mimpi Sejuta Dolar karya Alberthiene Endah. (2) mengkaji relefansi penerapan proses ekranisasi terhadap proses pembelajaran sastra di sekolah. Jenis penelitian ini adalah penelitian deskriptif kualitatif dengan pendekatan objektif dengan menggunakan teknik pengumpulan data berupa teknik baca, menyimak, dokumentasi, dan teknik catat. Hasil dalam penelitian berupa proses penciutan alur ditemukan 59 data, proses penambahan alur terdapat 12 data, sedangkan proses perubahan variasi alur sebanyak 14 data. Dari aspek relevansi terhadap pembelajaran sastra di sekolah, maka hasil penelitian ini dapat dijadikan sebagai penunjang. Proses penciutan alur secara keseluruhan masih wajar, dan penambahan alur dalam film menyebabkan pengisahan melenceng dari jalan cerita yang ada pada novel, sedangkan pada kategori aspek perubahan variasi alur terjadi variasi-variasi antara novel dan film dari segi alur yang tidak membuat pengurangan pada aspek makna yang terdapat di dalamnya. Penerapan hasil penelitian belum bisa diterapkan secara utuh pada jenjang Sekolah Menengah Pertama (SMP) dan Sekolah Menengah Atas (SMA), tapi masih relevan jika akan digunakan sebagai bahan penunjang untuk memperkaya wawasan siswa pada materimateri tertentu pada pembelajaran sastra.
\end{abstract}

Kata Kunci: Ekranisasi, Pembelajaran Sastra, Novel, Film

\section{Pendahuluan}

Pada era audio visual sekarang ini film sudah muncul sebagai salah satu sentra industri kreasi yang sudah mendapat posisi tersendiri di kalangan penikmat tayangan bergambar. Film sebagai karya seni naratif yang diciptakan dalam bentuk gabungan antara audio dan visual belakangan dianggap sebagai bagian perkembangan dari karya sastra. Bluestone (Eneste, 1991:18) menyatakan bahwa film merupakan gabungan dari berbagai ragam kesenian, yaitu musik, seni rupa, drama, sastra yang ditambah dengan unsur fotografi.

Pada perkembangannya adaptasi karya sastra khususnya karya novel banyak diadaptasi untuk diangkat menjadi karya film ditanah air. Fenomena perubahan karya 
sastra ke dalam bentuk film telah terjadi sejak beberapa dekade, sejumlah film yang sukses, khususnya dari segi jumlah penonton dan apresiasi masyarakat merupakan film yang diangkat dari karya sastra seperti novel ataupun kumpulan cerita. Pada umumnya karya sastra yang banyak diangkat menjadi suatu karya film adalah novel, pengambilan suatu karya novel menjadi film tentunya disertai dengan banyak pertimbangan didalamnya seperti bagaimana keberterimaan novel tersebut di mata pembacanya. Salah satu indikator novel yang berterimaan dengan pembacanya adalah bagaimana indeks peredaran atau penjualan novel tersebut yang biasa dilabeli sebagai novel best seller.

Proses adaptasi novel menjadi film yang merupakan perubahan substansi dari wacana yang lebih dikenal dengan istilah proses ekranisasi. Ekranisasi merupakan suatu pengubahan dari kata-kata menjadi wahana gambar, yang dalam proses pengalih wahananya turut pula penyesuaian dan perubahan unsur unsur didalamnya, baik itu berupa penciutan, penambahan, ataupun perubahan variasi. Salah satu unsur yang tentunya sangat memegang peranan dalam pembentukan cerita film yang diadaptasi dari sebuah novel adalah unsur alur cerita. Pembentukan suatu alur pada karya novel akan sangat berbeda dengan proses pembentukan alur pada film. Penggambaran dan penjabaran suatu peristiwa dalam sebuah novel akan dilakukan dengan mudah karena terjabarkan dengan bahasa tulis, hal berbeda akan dijumpai pada dunia perfileman yang dimana pengalurannya akan dibangun dengan proses yang rumit karena menggabungkan semua unsur bahasa lisan, gestur dan interaksi langsung oleh para pemainnya, belum lagi unsur pendukung lainnya seperti ilustrasi latar dan setting yang harus betul menjadi suatu kepaduan audio visual dalam film. Pada proses ekranisasi ini, alur akan menjadi faktor yang sangat dipertimbangkan bagaimana mengangkat suatu rangkaian peristiwa yang ada dalam novel berupa bahasa tulis untuk dituangkan menjadi audio visual dalam film tanpa mengaburkan jalannya suatu cerita dalam novel.

Beberapa penelitian yang relevan dengan penelitian ini diantaranya oleh Armiaty (2018) dengan judul"Ekranisasi Novel Assalamualaikum Beijing ke dalam film Assalamualaikum Beijing. Dalam hasil penelitiannya disebutkan terjadi beberapa perubahan hasil ekranisasi novel kedalam bentuk film berupa pengurangan tokoh, alur, latar. Penelitian serupa juga dilakukan oleh Mursi (2019) dengan judul penelitian Transformasi Novel ke Film The Perfect Husband Karya Indah Riyana, yang hasil penelitiannya menunjukkan penciutan atau pengurangan, penambahan dan variasi, menyebabkan perubahan alur dari novel ke film. Dari hasil pengkajian terkait penelitian yang relevan, hampir kesemuanya mendekati dua bentuk hasil penelitian tersebut di atas. Pada umumnya hanya melihat sekilas terkait bagaimana perubahan unsur dalam novel menjadi film dan tidak ditemukan hasil kajian lanjutan terkait bagaimana penerapannya dalam pembelajaran di Sekolah- sekolah (SMP dan SMA), sehingga peneliti tertarik meneliti bagaimana hasil proses ekranisasi dapat diterapkan pada pembelajaran sastra di jenjang SMP dan SMA.

Dari uraian-uraian di atas maka permasalahan yang akan diteliti dalam penelitian ini adalah bagaimana proses ekranisasi unsur alur yang meliputi penciutan, penambahan, ataupun perubahan variasi, dengan mengangkat studi kasus pada adaptasi Novel Mimpi Sejuta Dolar Karya Alberthiene Endah yang telah diangkat ke layar kaca yang kemudian dilihat relefansinya terhadap pembelajaran sastra di sekolah. Dari segi sisi urgensi, secara praktis penelitian ini diharapkan mampu memberikan sumbangsi penerapan dalam pembelajaran sastra dengan menggunakan kajian ekranisasi. 


\section{Kerangka Teori}

\section{Ekranisasi}

Ekranisasi merupakan suatu pengubahan dari kata-kata menjadi wahana gambar. Alur utama dalam novel adalah kata-kata, segala sesuatu disampaikan dengan kata-kata. Cerita, alur, penokohan, latar, suasana, dan gaya sebuah novel dibangun dengan kata-kata. Pemindahan novel ke layar putih, berarti terjadinya perubahan pada alat-alat yang dipakai, yakni mengubah dunia kata-kata menjadi dunia gambar-gambar yang bergerak berkelanjutan sebab di dalam film, cerita, alur, penokohan, latar, suasana, dan gaya diungkapkan melalui gambar-gambar bergerak berkelanjutan (Eneste, 1991: 60). Boggs (Asrul Sani, 1997: 23-25) menyatakan bahwa film dan novel memiliki kesamaan, yakni berfungsi sebagai media bercerita atau memiliki unsur naratif yaitu alur, penokohan, latar, suasana, gaya, dan tema/amanat novel yang terdapat pula dalam film sehingga film dan novel dapat dianalisis bersama-sama. Eneste (1991: 61-66) mengatakan pemindahan dari novel ke layar lebar atau film mau tidak mau akan menimbulkan berbagai perubahan dalam film yang disebut pula dengan proses dalam ekranisasi, proses ekranisasi tersebut adalah (1) penciutan, (2) penambahan dan (3) perubahan variasi.

Dalam penciutan, novel-novel tebal harus mengalami beberapa penghilangan, pemotongan, atau pereduksian bila hendak difilmkan. Hal tersebut berarti tidak semua hal yang diungkapkan dalam novel akan dijumpai pula dalam film. Sebagian alur, tokoh, latar ataupun unsur lainnya yang ada dalam novel akan ditemui dalam film, biasanya pembuat film (penulis skenario atau sutradara) telah memilih bagian-bagian atau informasi-informasi yang dianggap penting untuk ditampilkan. Dalam mengekranisasi tokoh, alur, latar, dan unsur lainnya akan mengalami penciutan oleh sebab itu hal-hal yang berada dalam novel yang penting-penting saja atau yang mempunyai pengaruh dalam cerita yang difilmkan (Eneste, 1991: 61-64).

Dalam hal Penambahan biasanya dilakukan oleh penulis skenario dan sutradara karena mereka telah menafsirkan novel yang akan mereka filmkan sehingga akan terjadi penambahan disana sini. Di samping adanya pengurangan tokoh, dalam ekranisasi juga memungkinkan adanya penambahan tokoh yang dalam novel tidak dijumpai sama sekali, tetapi dalam film ditampilkan. Menurut Eneste (1991: 64- 65). Penambahan dalam proses ekranisasi tentu mempunyai alasan, misalnya dikatakan bahwa penambahan itu penting, jika diamati dari sudut pandang filmis. Selain itu, penambahan dilakukan karena masih relevan dengan cerita secara keseluruhan.

Penambahan dalam ekranisasi memungkinkan terjadinya variasi-variasi tertentu dalam film.Walaupun terjadi variasi-variasi antara novel dan film, biasanya tema atau amanat dalam novel masih tersampaikan setelah difilmkan. Menurut Eneste (1991: 66) novel bukanlah dalih atau alasan bagi pembuat film, tetapi novel betul-betul hendak dipindahkan ke media lain yakni film. Perbedaan alat-alat yang digunakan, terjadilah variasi-variasi tertentu disana sini.Selain itu, dalam pemutaran film pun mempunyai waktu yang terbatas sehingga penonton tidak bisa untuk tetap menikmati sampai akhir, sehingga tidak semua hal atau persoalan yang dalam novel dapat dipindahkan semua ke dalam film. 


\section{Alur Cerita}

Alur adalah rangkaian peristiwa direka dan dijalani dengan saksama membentuk alur yang menggerakkan jalannya cerita melalui rumitan ke arah klimaks dan selesaian Sudjiman (Budianta dkk, 2006: 86). Sejalan dengan pendapat Aminuddin, 2013: 83 bahwa Alur adalah rangkaian cerita yang dibentuk oleh tahapan-tahapan peristiwa sehingga menjalin suatu cerita yang dihadirkan oleh para pelaku dalam suatu cerita. Pada proses pengaluran terdapat tiga tahapan yaitu (1) tahap awal (beginning), tahap tengah (middle), dan tahap akhir (end).

Tahap awal sebuah cerita biasanya disebut tahap perkenalan. Tahap perkenalan pada umumnya berisi sejumlah informasi penting yang berkaitan dengan berbagai hal yang akan dikisahkan pada tahap-tahap berikutnya. Selanjutnya adalah tahap tengah cerita, tahap ini dapat disebut dengan tahap pertikaian.Menampilkanpertentangan dan atau konflik yang sudah mulai muncul pada tahap sebelumnya.Konflik dapat berupa konflik internal, dan konflik eksternal. Terakhir adalah Tahap akhir sebuah cerita atau bisa disebut tahap penyelesaian. Menampilkan adegan tertentu akibat klimaks. Cerita pada bagian ini berisi bagaimana kesudahan cerita.Dalam teori klasik yang berasal dari Aristoteles penyelesaian cerita dibedakan kedalam dua macam kemungkinan, yaitu kebahagiaan (happy end), dan kesedihan (sad end).

\section{Unsur-unsur Alur}

Dalam alur terdapat beberapa unsur yang penting untuk mengembangkan sebuah cerita yang disajikan untuk para penikmatnya. Unsur tersebut ada tiga yaitu peristiwa, konflik dan penyelesaian. Peristiwa merupakan sesuatu yang terjadi dalam hidup, dapat mengesankan ataupun tidak. Menurut Luxemburg (Nurgiyantoro, 2013: 173). Peristiwa dapat diartikan sebagai peralihan dari satu keadaan ke keadaan yang lain berdasarkan pengertian itu, kita dapat membedakan kalimat-kalimat tertentu yang menampilkan suatu peristiwa, dalam hubungannya dengan pengembangan alur atau perannya dalam penyajian cerita.

Konflik (conflict) adalah kejadian yang tergolong penting berupa peristiwa fungsional dan utama merupakan unsur yang esensial dalam pengembangan plot. Konflik adalah suatu yang dramatik mengacu pada dua kekuatan yang seimbang dan menyiratkan adanya aksi dan aksi balas Wellek dan Wairen (Nurgiyantoro 2013: 179).

Tahap selanjutnya adalah tahap penyelesaian (Resolution). Di tahap ini, semua masalah yang tersaji di dalam cerita sudah terselesaikan. Tidak ada konflik lanjutan karena semua konflik sudah diselesaikan oleh sang tokoh di dalam cerita yang disajikan. Di tahap ini, pembaca atau penonton bisa menyimpulkan kesan yang mereka dapat dari cerita tersebut, sekaligus pesan atau amanat di balik cerita tersebut. Bila dibentuk suatu pola, maka tahapan alur berbentuk seperti berikut: (1) Tahap Pengenalan, (2) Tahap Kemunculan Konflik, (3) Tahap Konflik Memuncak, (4) Tahap Konflik Menurun, dan (5) Tahap Penyelesaian. 


\section{Metode}

Penelitian yang dilakasanakan dengan menggunakan jenis penelitian kualitatif. Penelitian kualitatif merupakan jenis penelitian yang menekankan kepada pendalaman dan interpretasi data dalam bentuk deskripsi. Proses pendeskripsian akan memberikan suatu pemahaman yang lebih komprehensif mengenai apa yang sedang dikaji (Semi, 2012: 31). Untuk mendeskripsikan proses ekranisasi dalam novel ini digunakan studi kasus pada ekranisasi novel Mimpi Sejuta Dolar, sehingga yang menjadi sumber data dalam penelitian ini adalah novel dan film Mimpi Sejuta Dolar tersebut. Data yang digunakan dalam penelitian ini adalah berupa kutipan novel dan episode film yang menunjang perubahan yang teridentifikasi sebagai proses transformasi alur cerita dari novel ke dalam bentuk film. Pengumpulan data ini menggunakan teknik baca, menyimak, dokumentasi, dan teknik catat. Analisis data dalam penelitian ini dilakukan secara interaktif dan berlangsung secara terus menerus sampai tuntas dengan tahapan mereduksi data, penyajian data dan penarikan kesimpulan.

\section{Hasil Penelitian dan Pembahasan}

\section{Proses Penciutan Alur}

Penciutan merupakan pengurangan dan penghilangan bagian dari novel yang tidak ditampilkan dalam film. Dari hasil penelitian, ditemukan 59 data yang diidentifikasi sebagai penciutan, yang terdiri dari: 29 data berupa proses pengurangan cerita dan 30 data berupa penghilangan cerita. Penciutan alur yang dilakukan secara keseluruhan masih wajar dilakukan karena terdapat perubahan pada beberapa tahap disebabkan durasi waktu film yang tidak mungkin bisa ditampilkan seutuhnya. Proses ekranisasi yang terjadi merupakan hal dalam novel yang dinikmati berjam-jam atau berhari-hari harus diubah menjadi hal yang dinikmati (ditonton) selama seratus enam menit. Dengan kata lain, novel setebal tiga ratus enam puluh dua halaman mengalami perubahan. Artinya, tidak semua hal yang diungkapkan dalam novel dinikmati dalam film. Sebagian cerita dalam novel dikurangi bahkan dihilangkan dalam film. Hal ini membuktikan bahwa penciutan unsur novel menjadi penyebab perubahan unsur film secara bervariasi.

\section{Proses Penambahan Alur}

Proses penambahan dalam analisis data terdapat pada bagian-bagian cerita yang ditambahkan dalam film tetapi tidak ada dalam novel. Pada bagian ini ditemukan 12 data yang mengalami penambahan cerita ke dalam film. Untuk Penambahan alur dalam film, ceritanya melenceng dari jalan cerita yang ada pada novel, karena pada novel Mimpi Sejuta Dolar lebih fokus pada cerita mengenai awal perjuangan Merry Riana hingga sukses Selain itu, film Mimpi Sejuta Dolar menvisualkan cerita tentang perjuangan Merry Riana untuk meraih kesuksesannya serta cerita mengenai kisah cinta antara Merry Riana dan Alva yang lebih ditonjolkan, sehingga di dalam film lebih menambah kisah daramatis tentang kisah asmara, agar penonton lebih tertarik dan antusias menonton film itu sampai akhir.

\section{Proses Perubahan Variasi Alur}

Ekranisasi memungkinkan terjadinya variasi-variasi tertentu antara novel dan film karena novel bukanlah alasan bagi pembuat film, melainkan novel diubah menjadi film sehingga film memunculkan perubahan yang variatif (Eneste, 1991: 65-66). 
Perubahan variasi adalah variasi penggambaran yang dilakukan dalam visualisasi dari novel ke film. Dalam ditemukan 14 data dalam film yang telah mengalami perubahan variasi. Walaupun terjadi variasi-variasi antara novel dan film, tapi maknanya masih tersampaikan meskipun jalan ceritanya dibuat berbeda dengan adanya perubahan cerita dan dari perbedaan alat-alat yang digunakan. Selain itu, dalam film pun mempunyai waktu yang terbatas sehingga penonton tidak bisa untuk tetap menikmati sampai akhir, sehingga tidak semua hal atau persoalan yang dalam novel dapat dipindahkan semua ke dalam film sehingga terjadilah perubahan variasi yang membuat jalan cerita dalam film lebih singkat dari novel.

\section{Relevansi terhadap pembelajaran Sastra di Sekolah}

Pembelajaran Sastra pada tingkatan Sekolah Menengah Pertama (SMP) dan Sekolah Menengah Atas (SMA) jika dilihat dari proporsi alokasi pembagiannya dengan pembelajaran Bahasa Indonesia pada umumnya adalah sangat sedikit, hal ini sejalan dengan pandangan Basir (2017) bahwa jika dilihat dalam perspektif "perkurikuluman", proporsi waktu lebih banyak tersita oleh bidang kebahasaan (90\%), sedang bidang sastra sangat sedikit (10\%). Dengan kondisi tersebut membuat pendalaman terkait kesusastraan sangatlah terbatas. Jika dilihat relevansi proses ekranisasi novel ke dalam film khususnya pada aspek unsur alur pada pembelajaran sastra di sekolah, maka penerapannya dapat diterapkan pada pembelajaran unsur-unsur pembangun karya sastra.

Pada jenjang tingkatan Sekolah Menengah Pertama (SMP), hasil pengkajian ini dapat menjadi rujukan referensi penambah wawasan terkait pengkajian sastra pada siswa. Pembelajaran ini dapat dijumpai pada pembelajaran Bahasa Indonesia kelas VII semester genap dengan materi pokok literasi buku fiksi dan nonfiksi, adapun kompetensi dasar adalah (1) Menemukan unsur-unsur dari buku fiksi dan nonfiksi yang dibaca, dan (2) Menyajikan tanggapan secaralisan, tulis, dan visual terhadap isi buku fiksi/nonfiksi yang dibaca. Pada kompetensi dasar pertama, hasil penelitian dapat diterapkan menjadi suplemen tambahan pada pembelajaran terkait bagaimana bentuk salah satu unsur pembangun karya berupa alur, baik itu pada novel ataupun film yang jika ingin ditelaah mendalam dapat dilihat bagaimana perubahan pengembangan keduanya. Hal ini akan membantu pada pencapaian indikator pembelajaran berupa siswa dapat Menentukan unsur-unsur buku fiksi. Sedangkan pada kompetensi dasar kedua, hasil penelitian ini dapat membantu siswa untuk dapat lebih memahai bagaimana proses alur dapat terbangun dalam sebuah karya sehingga siswa dapat mencapai indikator pembelajaran berupa Membuat komentar tentang buku fiksi yang dibaca.

Selain itu, pada kelas VIII semester genap penerapan hasil penelitian ini dapat diterapkan sebagai penunjang bahan pembelajaran dalam pembelajaran materi pokok teks drama, dengan sub materi pokok (1) unsur-unsur teks drama dan (2) penjelasan isi drama. Pada pembelajaran ini, hasil penelitian dapat diterapkan sebagai bahan pendekatan guna memberikan gambaran terkait bagaimana bentuk salah satu unsur pembangun karya sastra berupa unsur alur pada film yang juga bisa dikomparasi dengan alur pada karya novel, sehingga terdapat gambaran bagaimana proses gubahan bentuk alur dari karya tulis menjadi karya audio visual. Penerapan yang dilakukan akan membantu siswa dalam mencapai indikator siswa dalam mengidentifikasi dan menganalisis unsur dan isi drama.

Untuk jenjang tingkatan Sekolah Menengah Atas (SMA), penerapan hasil penelitian ini dapat diterapkan sebagai bahan penunjang pembelajaran, pada kelas XI semester ganjil. Dalam materi pokok nilai-nilai kehidupan dalam cerpen, hasil peneltian 
ini berupa alur novel ataupun film dapat dijadikan pembanding terkait nilai-nilai kehidupan pada suatu karya. Apalagi pada film, guna menarik siswa akan bagaimana siswa mampu mendapatkan/menemukan nilai-nilai kehidupan dalam karya sastra, siswa dapat diajak untuk nonton bersama yang dilanjutkan dengan diskusi lepas terkait bagaimana mereka mampu menemukan sesuatu yang berarti dari apa yang mereka lihat. Selanjutnya pada kelas XI semester genap, pada pembelajaran Bahasa Indonesia khusunya dalam materi drama dengan kompetensi dasar mengidentifikasi alur cerita, babak demi babak, dan konflik dalam drama yang dibaca atau ditonton, hasil penelitian ini dapat menjadi pembanding ataupun referensi terkait bagaimana mengidentifikasi alur dari drama yang ditonton. Dari hal tersebut juga dapat ditindak lanjuti dalam pemebelajaran kompetensi dasar selanjutnya berupa Menganalisis isi dan kebahasaan drama yang dibaca atau ditonton. Jadi, guna membantu guru dalam membuka serta menggali wawasan siswa, guru dapat memulai dengan menonton bersama kemudian berdiskusi terkait unsur alur yang mampu menggiring siswa menemukan unsur lainnya, sehingga siswa ada gambaran awal untuk dasar memasuki lebih dalam materi yang akan dipelajari dan guru bisa mendapat rujukan pemberian contoh dalam menjelaskan aspek unsur pembangun karya.

Selain itu, hasil penelitian ini juga bisa dijadikan bahan penunjang pembelajaran pada kelas XII terkait materi pokok isi dan kebahasaan novel. Khusus pada materi isi novel, dijumpai materi terkait unsur intrinsik novel, sehingga hasil pengkajian berupa alur novel bisa digunakan sebagai bahan referensi lain terkait bagaimana bentuk salah satu unsur pembangun novel yaitu berupa alur, hasil peneltian ini juga dapat dikembangkan ketika guru ingin mengajak siswa melihat bagaimana salah satu unsur pembangun mengalami proses gubahannya ke dalam bentuk audio visual sehingga menggiring siswa untuk lebih memahami pembelajaran. Secara umum Novel dan Film Mimpi Sejuta Dolar sangatlah mumpuni jika akan dijadikan sarana media pembelajaran sastra pada tingkatan Sekolah Menengah Pertama (SMP) dan Sekolah Menengah Atas (SMA), hal ini dikarenakan dari isi cerita sangat banyak memuat nilai pendidikan akan bagaimana perjuangan yang pantang menyerah dalam mengejar mimpi atau cita-cita menuju kesuksesan.

\section{Simpulan}

Berdasarkan hasil penelitian yang telah dilakukan peneliti, maka dapat diambil simpulan bahwa ekranisasi yang terdiri dari penciutan, penambahan, dan perubahan variasi berkaitan dengan alur cerita dan penerapannya dalam pembelajaran sastra pada tingkatan Sekolah Menengah Pertama (SMP) dan Sekolah Menengah Atas (SMA) adalah sebagai berikut:

1. Penciutan alur yang dilakukan dalam visualisasinya ke bentuk film secara keseluruhan masih wajar, hal tersebut dilakukan pada beberapa tahap disebabkan durasi waktu film yang tidak mungkin bisa ditampilkan seutuhnya.

2. Penambahan alur dalam film menyebabkan pengisahan melenceng dari jalan cerita yang ada pada novel, hal ini dilakukan agar alur dalam film tidak terlalu monoton seperti halnya dalam novel.

3. Kategori aspek perubahan variasi alur terjadi variasi-variasi antara novel dan film dari segi alur atau jalan ceritanya yang tidak membuat pengurangan pada aspek makna yang terdapat di dalamnya

4. Penerapan hasil penelitian berupa ekranisasi novel ke dalam film secara langsung belum bisa diterapkan secara utuh. Hal ini dikarenakan pembelajaran sastra pada 
jenjang Sekolah Menengah Pertama (SMP) dan Sekolah Menengah Atas (SMA) belum mengajarkan alih bentuk karya sastra. Meskipun demikian hasil penelitian ini masih relevan jika akan digunakan sebagai bahan penunjang untuk memperkaya wawasan siswa pada materi-materi tertentu, seperti unsur pembangun karya, dan bentuk kebahasaan karya sastra.

\section{UCAPAN TERIMA KASIH}

Pelaksanaan penelitian ini tidak terlepas dari dukungan beberapa pihak sehingga ucapan terima kasih dan penghargaan yang setinggi-tingginya diberikan kepada:

1. Direktorat Sumber Daya Direktorat Jenderal Pendidikan Tinggi Kementrian Pendidikan, Kebudayaan, Riset dan Teknologi sebagai pemberi dana dalam pelaksanaan Penelitian Dosen Pemula.

2. Rektor Universitas Sembilanbelas November Kolaka dan Lembaga Penelitian, Pengabdian dan Penjamian Mutu Pendidikan (LP2M-PMP) Universitas Sembilanbelas November Kolaka, yang telah memberi perizinan dan arahan dalam pelaksanaan penelitian ini.

3. Pihak Dekan dan Wakil Dekan Fakultas Keguruan dan Ilmu Pendidikan (FKIP) Universitas Sembilanbelas November Kolaka beserta jajaran, yang telah mendukung sepenuhnya dalam pelaksanaan kegiatan ini.

4. Ketua Jurusan Bahasa dan Ketua Program Studi Pendidikan Bahasa Indonesia, serta rekan dosen Program Studi Pendidikan Bahasa Indonesia Fakultas Keguruan dan Ilmu Pendidikan (FKIP) Universitas Sembilanbelas November Kolaka yang telah bekerja sama dalam menyelesaikan penelitian ini.

5. Mahasiswa Program Studi Pendidikan Bahasa Indonesia yang telah terlibat dalam pelaksanaan kegiatan ini, serta semua pihak yang belum sempat disebutkan satu persatu.

\section{Daftar Pustaka}

Aminuddin. 2013. Pengantar Apresiasi Karya Sastra. Bandung: Sinar Baru Algesindo.

Armiati, Y. (2018). Ekranisasi Novel Assalamualaikum Beijing Ke Dalam Film Assalamualaikum Beijing. Master Bahasa, 6(3), 301-310.

Basir, U. P. M. (2017). Aspek “Kesastraan” Dalam Kurikulum Bahasa Indonesia: Sejumlah Problematika Terstruktur. FKIP e-PROCEEDING, 227-236.

Budianta, M. dkk. 2002. Membaca Sastra. Magelang: Indonesiatera.

Eneste, P. 1991. Novel dan Film. Flores. Nusa Indah. 
ISSN 2443-3667 (print) 2715-4564 (online)

Mursih, M., \& Nursalim, M. P. (2019). TRANSFORMASI NOVEL KE FILM THE PERFECT HUSBAND KARYA INDAH RIYANA. Jurnal Sasindo UNPAM, 7(2), 87-101

Nurgiyantoro, B. 2013. Teori Pengkajian Fiksi. Yogyakarta: Gadjah Mada University Press.

Sani. A. 1997 “Teater Modern Indonesia : Pustaka Jaya.

Semi, M. Atar. 2012. Metode Penelitian Sastra. Bandung: Angkasa.

Sugiyono. 2014. Metode Penelitian Pendidikan Pendekatan Kuantitatif, Kualitatif, dan R\&D. Bandung: Alfabeta

Wellek, R. dkk. 2014. Teori Kesusastraan. Jakarta: Gramedia 